Installation Technology Transfer Program

Army Facility Standard Design and ISR-I Mission Criteria Alignment

Michael N. Grussing, Kelly M. Dilks, and Matthew C. Walters

September 2011 



\section{Army Facility Standard Design and ISR-I Mission Criteria Alignment}

Michael N. Grussing, Kelly M. Dilks, and Matthew C. Walters

Construction Engineering Research Laboratory

US Army Engineer Research and Development Center

2902 Newmark Drive

Champaign, IL 61822

Final report

Approved for public release; distribution is unlimited.

Prepared for Office of the Assistant Chief of Staff for Installation Management (ACSIM)

Arlington, VA 22202

Under Project FY10-12E, "SMS-ISR Integration" 


\begin{abstract}
This report describes a process for integrating US Army Standards and Standard Designs with assessment criteria used in the Army Installation Status Report for Infrastructure (ISR-I). Army-specific missioncritical facility criteria were identified for two Tier 1 building types, the Tactical Equipment Maintenance Facility and the Company Operations Facility. These criteria were established to meet fundamental performance requirements of the subject facilities. Non-conformance to these criteria could result in the inability of the facility to support its mission, thus requiring restoration, modernization, or replacement. It is imperative that these criteria be incorporated into any assessment process for existing facilities that are used for the same purpose.
\end{abstract}

The objectives of the current project were to (1) identify Army missionperformance criteria that are embedded in and required by Army Standards and Standard Designs and (2) identify the steps for integrating these mission criteria into the ISR-I to provide decision support for facility Sustainment, Restoration, and Modernization (SRM). Facilities failing to meet mission requirements and not structurally capable of being modernized under SRM are referred to the Military Construction Integrated Process Team for prioritization within the MILCON program. This report describes the results of these efforts and provides recommendations.

DISCLAIMER: The contents of this report are not to be used for advertising, publication, or promotional purposes. Citation of trade names does not constitute an official endorsement or approval of the use of such commercial products. All product names and trademarks cited are the property of their respective owners. The findings of this report are not to be construed as an official Department of the Army position unless so designated by other authorized documents. 


\section{Executive Summary}

The Army Facilities Standardization Process is a joint effort between Headquarters Army elements and the US Army Corps of Engineers. Facility standards are developed by the Facility Design Group. Once the criteria for an Army Standard are complete and vetted through the responsible Gstaff office, the Army Centers of Standardization (COS) develop and publish them as Army Facility Standard Designs. While these documents specify requirements and features for a newly constructed facility, a vast majority of existing Army facilities were not built to meet those same standards because construction preceded the standards publication. Nevertheless, it is necessary to evaluate the performance of these existing facilities against the latest facility requirements in order to understand how these facilities can support the Army's current and future projected technology, materiel, and weapons systems. The Army's established process to assess the condition, performance, and readiness of facilities is the Installation Status Report for Infrastructure (ISR-I). While the ISR-I criteria have recently been updated to distinguish between condition-related quality issues and mission-related issues, current Army Standards and Standard Designs are not fully incorporated into these mission criteria.

The objective of this project was to identify the specific building configuration criteria embodied in Army Standard Designs to serve as missionrelated criteria for ISR-I. Army standard mission criteria were categorized for two Tier 1 facilities - the Tactical Equipment Maintenance Facility (TEMF) and the Company Operations Facility (COF). These criteria were then organized and linked to the ISR-I data structure for components and elements of each building type, becoming part of the ISR-I rating criteria for the FY11 rating cycle. Guidance for incorporating information and assessment criteria was developed as part of this project.

\section{Benefits}

While the ISR-I assessment process attempts to identify facility requirements affecting readiness and mission, there has been no formalized process to incorporate current Army Standards and Standard Designs into the assessment criteria. As a result, current ISR-I mission ratings are not synchronized with Army Standards and Standard Designs. This project aligns Fiscal Year 2011 ISR-I mission-critical facility elements for the 
TEMF and COF with Army Standards and Standard Designs. This criteria alignment facilitates the ability of Army installations to evaluate their existing buildings and collect data that are relevant to Army Standards and Standard Designs. It allows a consistent comparison against the latest Army standards baseline, identifies facility inadequacies in terms of mission requirements, and supports installation readiness reporting to Defense Readiness Reporting System, Army (DRRS-A). It also improves the prioritization of SRM funding for solider/mission readiness, and provides more accurate input to the development of future Military Construction (MILCON) budgets and projections.

\section{Costs}

The successful implementation of this integration process may require a marginal extra effort in the area of data collection. The return on that marginal cost will be the capture of more accurate and relevant facility data and assurance of its alignment with the latest Army Standards, Standard Designs, and mission criteria. The implementation of this criteria alignment will make it possible for the first time to formulate a meaningful comparison between the performance of existing buildings and new, stateof-the-art facilities with respect to current facility requirements.

\section{Recommendation}

It is recommended that these building performance assessment criteria be integrated with the Army's existing ISR-I assessment process. Army ISR-I criteria require modification to standardize the mission-related facility criteria and incorporate the latest Army Standards and Standard Designs. The research team has prepared a list of recommended the ISR-I mission criteria modifications to include facility-specific Army standard criteria, as presented in Appendices A and B. The recommended modifications were coordinated with the proponents for the TEMF (G-4 office) and the COF (G-3/5/ 7 office and FORSCOM). The Army ISR-I team incorporated the mission criteria revisions into the FY11 ISR-I Standards Rating Booklets for the TEMF and COF. Upon completion of these facility types, the research team recommends the application of this procedure and updating the ISR-I booklets for other Tier 1 facilities, including the Command and Control Facility (C2F) and the Brigade and Battalion Headquarters (Bge/ Bn HQs). This will improve the results of future ISR-I data collection cycles by determining mission-critical functional components in conjunc- 
tion with the Facility Design Group responsible for the definition of Army Standards.

Finally, the research team recommends that ISR-I changes to the mission rating guidelines be addressed in annual ISR-I training activities. This training support will facilitate input by ISR-I assessors to consider in future efforts or to coordinate with Facility Design Groups in conjunction with Offices of G-3/5/7/ and G-4. These changes can be expected to increase the visibility of Army Standards to installation personnel and promote a common understanding of which parts of a facility are most mission-critical. 


\section{Table of Contents}

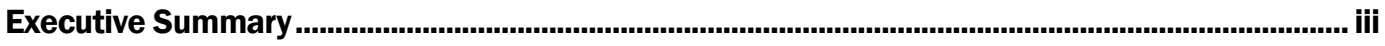

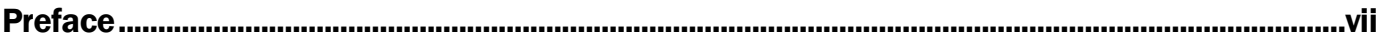

Unit Conversion Factors …........................................................................................................... viii

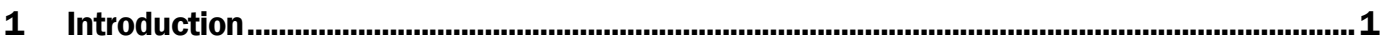

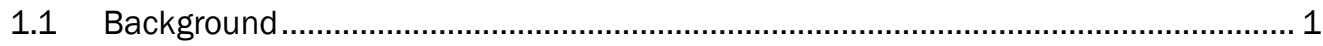

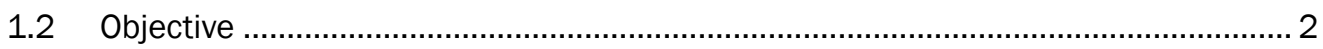

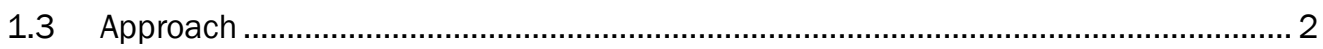

1.4 Mode of technology transfer .......................................................................... 3

2 Aligning Army Standards and ISR-I Criteria for the TEMF and COF.................................... 4

2.1 Identification and organization of Army standard criteria ......................................... 4

2.2 Determination of mission-critical functional criteria ................................................ 4

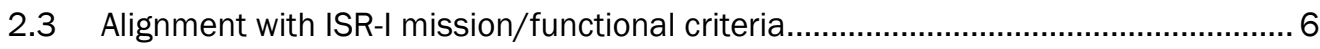

2.4 Priorities and allocations assigned to each component ........................................ 7

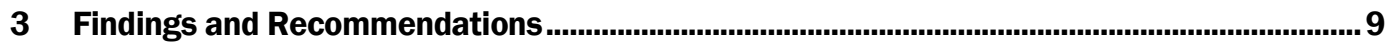

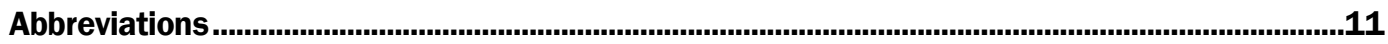

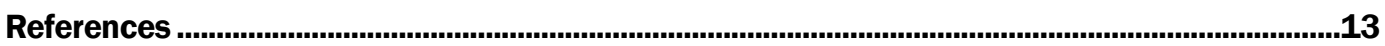

Appendix A: Army Standard Criteria for Company Operations Facilities (COF) ............................14

Appendix B: Army Standard Criteria for Tactical Equipment Maintenance Facilities

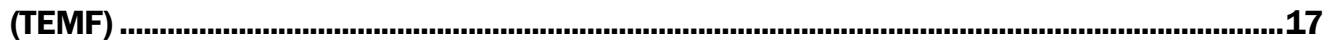

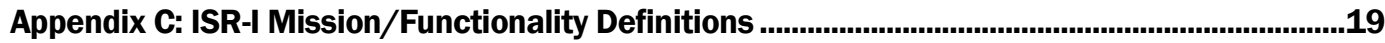

Report Documentation Page 


\section{Preface}

This study was conducted for the US Army Assistant Chief of Staff for Installation Management (ACSIM) under Installation Technology Transfer Program (ITTP) Project ITTP FY10-12E, "SMS-ISR Integration." The technical reviewer for ACSIM was Philip Columbus, DAIM-ODF.

The work was performed by the Engineering Processes Branch (CF-N) of the Facilities Division (CF), US Army Engineer Research and Development Center - Construction Engineering Research Laboratory (ERDC-CERL). The ITTP Program Manager was Debbie J . Lawrence, CEERD-CV-ZT. At the time of publication, Donald K. Hicks was Chief, CEERD-CF-N; L. Michael Golish was Chief, CEERD-CF; and Martin J . Savoie was the Technical Director for Installations, CEERD-CV-ZT. The Deputy Director of ERDC-CERL was Dr. Kirankumar Topudurti and the Director was Dr. Ilker Adiguzel.

COL Kevin Wilson was the Commander and Executive Director of ERDC, and Dr. J effery P. Holland was the Director. 


\section{Unit Conversion Factors}

\begin{tabular}{|l|c|l|}
\hline Multiply & By & To Obtain \\
\hline Acres & $4,046.873$ & square meters \\
\hline cubic feet & 0.02831685 & cubic meters \\
\hline cubic inches & 0.00001638706 & cubic meters \\
\hline degrees (angle) & 0.01745329 & radians \\
\hline degrees Fahrenheit & $(5 / 9) \times\left({ }^{\circ} \mathrm{F}-32\right)$ & degrees Celsius \\
\hline degrees Fahrenheit & $(5 / 9) \times\left({ }^{\circ} \mathrm{F}-32\right)+$ & kelvins \\
\hline Feet & 273.15. & meters \\
\hline gallons (US liquid) & 0.3048 & cubic meters \\
\hline horsepower (550 ft-lb force per & 0.003785412 & watts \\
\hline second) & 745.6999 & meters \\
\hline Inches & 0.0254 & kilopascals \\
\hline kips per square foot & 47.88026 & megapascals \\
\hline kips per square inch & 6.894757 & kilometers \\
\hline miles (US statute) & 1.609347 & newtons \\
\hline pounds (force) & 4.448222 & megapascals \\
\hline pounds (force) per square inch & 0.006894757 & kilograms \\
\hline pounds (mass) & 0.4535924 & square meters \\
\hline square feet & 0.09290304 & square meters \\
\hline square miles & $2,589,998$ & newtons \\
\hline tons (force) & $8,896.443$ & kilograms \\
\hline tons (2,000 pounds, mass) & 907.1847 & meters \\
\hline Yards & 0.9144 & \\
\hline
\end{tabular}




\section{Introduction}

\subsection{Background}

The Army Facilities Standardization process is a joint effort between Headquarters Army elements and the US Army Corps of Engineers. Each facility standard is developed by an assigned Facility Design Group. Once the criteria for an Army Standard are complete and vetted through the responsible G-staff office, the Army Centers of Standardization (COS) develop and publish them as Army Facility Standard Designs. These documents specify current requirements and features for a newly constructed facility, but a vast majority of the Army's existing facilities were not built to meet those same standards because construction preceded the standards publication. Nevertheless, it is necessary to evaluate the performance of these existing facilities against the latest facility requirements in order to understand how these facilities can support the Army's current and future projected technology, materiel, and weapons systems.

The Army's established process to assess the condition, performance, and readiness of facilities is the Installation Status Report for Infrastructure (ISR-I). The ISR-I was established to provide a quantifiable metric for facility quality (conditions in need of maintenance and repair) and quantity (adequate amount of a particular facility type) on Army installations. Following a widely used scoring convention, a facility is rated Green, Amber, or Red based on its condition. Using barracks as an example, the quantity metric determines whether there is enough barracks space at an installation to house all of the soldiers. The quality rating addresses the physical condition of the barracks buildings at the installation. These data help to determine the priorities for allocating Army military construction, rehabilitation, and repair dollars. Independently of quantity and condition metrics, a facility also must be configured appropriately to support the mission of its tenants. The mission assigned and the type of facility relate to the overall design of the building, including its layout and the presence of any required systems or components. This determination is independent of facility degradation and repair needs, but directly indicates whether a facility is considered to be functional for specified mission requirements. It is measured by a separate mission functionality index in ISR-I. With the 
move to DOTMLPF1, facilities are identified by TRADOC as essential to the Army, and with the implementation of the Defense Readiness Reporting System, Army (DRRS-A), the mission function of a facility has become part of the ISR-I.

While the ISR-I criteria have recently been updated to distinguish between condition-related quality issues and mission-related issues, current Army Standards and Standard Designs are not fully incorporated into these mission criteria. When the facility standards are incorporated, Army installations will be able to evaluate their buildings and collect data based on the latest facility mission requirements. This will allow consistent comparison of existing buildings against the latest Army facility standards baseline.

More comprehensive and aligned ISR-I criteria directly support goal 1 of the 2007 Defense Installations Strategic Plan to locate, size, and configure defense installation assets to meet the required capabilities of military forces. Criteria alignment provides for better-targeted revitalization of existing inventories by identifying where SRM is cost effective versus new construction. Other key policy drivers related to this project include:

- $\mathrm{AR} 420-1$

- Defense Readiness Reporting System (DRRS) Requirements for Q ratings

- EO 13327 for Federal Real Property Asset Management.

Making the ISR-I data collection capability available to determine the mission functionality rating for mission-critical Tier 1 facilities will enhance MILCON and SRM (Sustainment, Restoration, Modernization) planning.

\subsection{Objective}

The objective of this project was to identify the specific building configuration criteria embodied in Army Standards and Standard Designs to serve as mission-related functionality criteria for ISR-I.

\subsection{Approach}

This project categorized the critical Army Standards and Standard Designs for two Tier 1 facilities - the Tactical Equipment Maintenance Facility

\footnotetext{
${ }^{1}$ DOTMLPF: Doctrine, Organization, Training, Material, Leadership, Personnel, Facilities.
} 
(TEMF ) and the Company Operations Facility (COF) - in order to identify gaps between the standards and actual facility inventory information. The work was accomplished through an extensive review of the Army Standards and Standard Designs, which was coordinated with the facility type proponents and Facility Design Groups. Once identified, these criteria were organized and linked to the ISR-I data structure for components and elements of each building type, which becomes part of the ISR-I rating criteria for the FY11 rating cycle.

\subsection{Mode of technology transfer}

The results of this project will be implemented in Army practice as part of the ISR-I data collection methodology for the purpose of prioritizing MILCON and SRM budgeting decisions to better align with Army facility mission requirements. 


\section{Aligning Army Standards and ISR-I Criteria for the TEMF and COF}

The TEMF and the COF were the first two facility types that the MILCON Integrated Process Team (IPT) requested for incorporation into the ISR-I based on their priority in the upcoming MILCON planning and budgeting cycle. These two facility types are the next to be targeted for improvement across the Army due to changes in the required configurations to meet new mission requirements. For example, nearly all COFs built before 2005 do not have adequate storage units for tactical field gear (i.e., TA-50), and these are vital because many soldiers are now issued up to seven duffel bags, including cold-weather gear, before deployment.

\subsection{Identification and organization of Army standard criteria}

The first step in integrating Army standard criteria into the ISR-I was a comprehensive review and decomposition of the Army Standard and Army Standard Design documents into detailed and tabulated criteria elements. This work began under a prior-year project documented in ERDC/ CERL Technical Report TR-10-17 (Grussing et al. 2010). The criteria for the COF and TEMF were organized and compared against ISR-I mission functional criteria, and gaps were identified. The TEMF falls under Army Facility Category Group (FCG) 21410 - Vehicle Maintenance Shops, which is addressed by ISR-I Standards Rating Booklet 6, "Maintenance Facilities Unit Readiness." The COF falls under FCG 14185 - Company Headquarters Building, which is addressed by ISR-I Standards Rating Booklet 19, "Unit Operations Buildings."

\subsection{Determination of mission-critical functional criteria}

The criteria as discussed in the step above are then ranked in terms of its mission-critical elements. This was accomplished with feedback from facility users and the proponents for each facility. The Army proponent for the TEMF is the Office of G4, and the Army proponent for the COF is the Office of G3/5/ 7. This feedback ensures that the mission-critical elements as identified in the Army Standards and Standard Designs receive the appropriate priority 1, 2, or 3 rating. Feedback from the facility proponent and user community to identify critical criteria was presented as follows, for the COF example: 
1. Priority 1Elements:

a. Arms Room:

i. RED: Not enough room to store all unit equipment, even packed in.

ii. AMBER: Equipment fits, but requires use of aisles.

iii. GREEN: Equipment fits together with and in appropriate storage racks/ lockers.

b. Secure non-sensitive storage:

i. RED: Not enough room to store all unit equipment, even packed in.

ii. AMBER: Equipment fits, but requires use of aisles.

iii. GREEN: Equipment fits together with and in appropriate storage racks/ lockers.

C. Unit Supply:

i. RED: Not enough room to store all unit equipment, even packed in.

ii. AMBER: Equipment fits, but requires use of aisles.

iii. GREEN: Equipment fits together with and in appropriate storage racks/ lockers.

d. Communications equipment storage (can include storage for electronic warfare gear):

i. RED: Not enough room to store all unit equipment, even packed in.

ii. AMBER: Equipment fits, but requires use of aisles.

iii. GREEN: Equipment fits together with and in appropriate storage racks/ lockers.

e. NBC storage (also can store asymmetric warfare and C-IED gear):

i. RED: Not enough room to store all unit equipment, even packed in.

ii. AMBER: Equipment fits, but requires use of aisles.

iii. GREEN: Equipment fits together with and in appropriate storage racks/ lockers.

f. TA-50 Storage:

i. RED: Insufficient to support all non-barracks soldiers.

ii. AMBER: Supports all non-barracks soldiers, but insufficient for all in-barracks soldiers.

iii. GREEN: Sufficient for all soldiers.

2. Priority 2 Elements:

a. Admin module (command group offices, platoon offices, conference room, latrine, and NIPR/ SIPR connectivity): 
i. RED: Lack offices for CDR, 1SG, OPS SGT, XO; or Lacks NIPR/SIPR.

ii. AMBER: Lack company conference room, platoon offices, or latrine in building.

iii. GREEN: Has offices for CDR, 1SG, OPS SGT, XO; and has NIPR/ SIPR; and has company platoon offices and conference room, and latrine in building.

b. Site Orientation (near barracks and motor pool/TEMF):

i. RED: More than 1/ 4 mile from unit's barracks.

ii. AMBER: More than 1/4 mile from the unit's motor pool, but within 1/4 mile of the unit's barracks.

iii. GREEN: Within 1/4 mile of both barracks and motor pool.

c. Covered Hardstand (TA-50 layout/ inspection area):

i. RED: Has none or is not collocated within 100 meters of the COF.

ii. AMBER: Has limited, undersized (per facility standard).

iii. GREEN: Has adequately sized covered hardstand located adjacent to $\mathrm{COF}$.

\subsection{Alignment with ISR-I mission/functional criteria}

After the mission-critical components of the facility were identified and ranked, this information was compared with the existing mission criteria in the ISR-I Standards Rating Booklets. This step identified current gaps and the format in which new criteria should be inserted. The ISR-I booklets for a particular facility type (such as the COF or TEMF) are arranged according to facility components. Common components of a facility may include foundations, administrative spaces, the electrical system, the mechanical system, etc. There are also facility-specific components that are usually unique to the facility type. Most of the mission-critical components identified in the Army Standards fall into this facility-specific category.

These components are broken down further into individual elements, such as floors, walls, ceilings, etc., for an administrative space. Rating criteria (for Red, Amber, and Green conditions) are defined for each element. Therefore, the inspector conducting an ISR-I assessment is performing that rating at the building-element level. ISR-I criteria are divided into mission and quality criteria, which are each applied independently. The additional criteria identified during the Army Standards and Standard Design document review were included as mission-rating criteria. 
During the comparison with the existing ISR-I criteria, the mission criteria from the Army Standards and Standard Designs were arranged into components and elements to follow the ISR-I structure. In some cases, components and/or elements already existed, and the rating criteria were all that required updating. In other cases, such as the $\mathrm{COF}$, new facilityspecific components needed to be added to the ISR-I booklets. For the $\mathrm{COF}$, the following components were added to the ISR-I:

- Secure Non-Sensitive Storage

- Arms Vault

- NBC Storage

- Communications Equip Storage

- Unit Supply Storage

- TA-50 Lockers/ Equipment Area.

Associated with each of these components are elements and rating criteria, as shown in Appendix A. The new components provide the structure for the new criteria.

Although the new Army standard criteria only address mission ratings, and not quality criteria, if new components were added, they may require corresponding quality criteria to ensure consistency with the existing ISRI rating process. For example, for the new storage components addressed above, the same quality rating criteria used in the general Supply Storage component would also apply. For consistency, these elements (ceilings, floors, doors, walls, and space layout) were copied from the general Supply Storage component to each new facility-specific component. Due to the secure nature of these mission-critical storage spaces over and above supply storage, the following elements were also applied from the existing Arms Room component:

- Security

- Computer/ LAN System

- Lighting and Outlets

- Telephone System

- Lockers (for TA-50 Storage only).

\subsection{Priorities and allocations assigned to each component}

The purpose of the ISR-I assessment process is to get an overall rating of a facility. Based on the rating of the individual elements and components 
(i.e., Red, Amber, Green) and the importance or priority of those components, the assessment determines the building's functional and quality ratings. For the newly added mission-critical criteria from the Army Standards and Standard Designs, the impact on the overall mission functional rating may be summarized as follows:

- Any single Red rating on a Priority 1 mission-critical element results in an overall RED functional mission rating for a facility.

- Any single Red rating on a Priority 2 mission-critical element results in an overall AMBER functional mission rating for a facility.

- Two Red ratings on Priority 2 mission-critical elements result in an overall RED functional mission rating for a facility.

In addition to providing a facility rating, the ISR-I information also provides estimates on facility SRM costs. This is accomplished by estimating the cost to bring deficiencies identified during the inspection up to an Amber or Green quality rating. To maintain this capability, new components added to the ISR-I structure as part of this process require space allocations to be defined based on the size of the facility. For the COF, for example, the following percentages generally apply for its three main modules:

- Admin Module - 27\% (includes CO, XO, platoon offices, conference rooms, etc)

- Readiness Module - 58\% (includes the facility-specific storage spaces and arms vault)

- Exterior Covered Hardstand - 15\%.

The Readiness Module also includes additional facility element breakdowns:

- Secure Non-Sensitive Storage - $2 \%$

- Arms Vault - 3\%

- NBC Storage - $1 \%$

- Communications Equip Storage - $1 \%$

- Unit Supply Storage - 3.5\%

- TA-50 Lockers/ Equipment Area - 31\%. 


\section{Findings and Recommendations}

Army installations report the condition and readiness of their facility infrastructure assets using the ISR-I. Building tenants are primarily responsible for providing a condition/ readiness rating based on standardized guidelines that consider several different aspects of the facility. This process produces a Green, Amber, or Red rating for each the building. The facility-specific rating gets rolled up by facility category code (CATCODE). While the ISR-I assessment process attempts to identify facility requirements affecting readiness and mission, there has been no formalized process for incorporating current Army Standards and Standard Designs into the assessment. Army ISR-I criteria require modification to standardize the mission-related facility criteria and to incorporate all requirements of the latest Army Standard Standards and Standard Designs. This alignment of criteria and requirements makes it possible to assess facilities of different ages against a common and current baseline. The research team has recommended the ISR-I mission-criteria modifications to include facility-specific Army standard criteria (as identified in Appendix A and B). These modifications were coordinated with the proponents and the Army ISR-I team and incorporated in the FY11 inspection booklets for the TEMF and COF.

Based on the results of this project, the research team recommends that Army Standards and Standard Designs be integrated with the ISR-I criteria the Army currently uses to assess facilities. The additional Army ISR-I criteria will require only an incremental additional effort in data collection, but in turn it will provide more accurate data that are aligned with the latest Army Standards and Standard Designs. This criteria alignment allows a valid comparison of existing building performance with that of new-state-of-the art facilities, helping to ensure that installations provide the most suitable facilities feasible for Army units.

The annual ISR-I training program now includes guidance to facilitate the collection of accurate and consistent facility functionality information through the ISR-I criteria rating process. The research team recommends that these ISR-I criteria modifications and a general discussion of Army Standards and Standard Designs be incorporated into the annual ISR-I training program, to include rating guidelines, system data entry, and re- 
ports generation. This recommendation would generate feedback from ISR-I assessors to address in future efforts in coordination with Facility Design Groups in conjunction with the Offices of G-3/5/ 7/ and G-4. The result of this effort will be to elevate the visibility of Army Standards and Standard Designs to installation personnel.

Upon completion of work on the TEMF and COF criteria, the research team recommends application of this criteria alignment procedure and the updating of ISR-I booklets for other Tier 1 Army facilities, including the Command and Control Facility (C2F) and the Brigade and Battalion Headquarters (Bde/ Bn HQs). That work would improve the results of future ISR-I data collection cycles by determining mission-critical functional components in conjunction with the Facility Design Group. 


\section{Abbreviations}

1SG - 1st Sergeant

ACSIM - Assistant Chief of Staff for Installation Management

Bde- Brigade

Bn - Battalion

C2F - Command and Control Facility

CATCODE - Category Code

CDR - Commander

CERL - Construction Engineering Research Laboratory

$\mathrm{CO}$ - Commanding Officer

COF - Company Operations Facility

COS - Centers of Standardization

DOTMLPF - Doctrine, Organization, Training, Material, Leadership,

Personnel, Facilities

DRRS-A - Defense Readiness Reporting System, Army

ERDC - Engineer Research and Development Center

FCG - Facility Category Group

FORSCOM - US Army Forces Command

HQ - Headquarters

HVAC - Heating, Ventilation, and Air Conditioning

IPT - Integrated Process Team

ISR-I - Installation Status Report - Infrastructure

ITTP - Installation Technology Transition Program

MLCON - Military Construction

NBC - Nuclear, Biological, and Chemical (equipment)

Ops SGT - Operations Sergeant

NIPR - Non-Classified Internet Protocol Router Network 


\author{
SIPR - Secure Internet Protocol Router Network \\ SRM - Sustainment, Restoration, Modernization \\ TRADOC - Training and Doctrine \\ TEMF - Tactical Equipment Maintenance Facility \\ XO - Executive Office, Executive Officer
}




\section{References}

Department of the Army. (2008). "Standard Design for Tactical Equipment Maintenance Facility (TEMF) Complex." Memorandum. Arlington, VA: US Army Assistant Chief of Staff for Installation Management (ACSIM).

Department of the Army. (2004). "Standard Design for Company Operations Facilities." Memorandum. Arlington, VA: US Army Assistant Chief of Staff for Installation Management (ACSIM).

Department of the Army Facilities Standardization Program. (2010). Company Operations Facility Statement of Work. Savannah, GA: US Army Engineer District, Savannah.

Department of the Army Facilities Standardization Program (2010). Tactical Equipment Maintenance Facilities Standard Design. Savannah, GA: US Army Engineer District, Savannah.

Grussing, Michael N., Lance R. Marrano, and Matthew C. Walters et al. (2010). Development of Army Facility Functionality Assessment Criteria and Procedures, ERDC/ CERL Technical Report TR-10-17. Champaign, IL: US Army Engineer Research and Development Center, Construction Engineering Research Laboratory (ERDC-CERL).

Installation Status Report - Infrastructure. (2010). Standards Rating Booklet 6, "Maintenance Facilities - Unit Readiness."

Installation Status Report - Infrastructure. (2010). Standards Rating Booklet 19, “Unit Operations Buildings." 


\section{Appendix A: Army Standard Criteria for Company Operations Facilities (COF)}

\begin{tabular}{|c|c|c|}
\hline Component: & Arms Vault & Priority: \\
\hline \multirow[t]{5}{*}{ Green: } & \multicolumn{2}{|c|}{ Net Square Foot (NSF) Area meets or exceeds the following based on company personnel (PN): } \\
\hline & $100 \mathrm{PN}$ & 400 \\
\hline & $150 \mathrm{PN}$ & 500 \\
\hline & $200 \mathrm{PN}$ & 600 \\
\hline & Add'I 50 PN & 100 \\
\hline Amber: & \multicolumn{2}{|c|}{$\begin{array}{l}\text { Net Square Foot (NSF) Area does not meet space requirements addressed under Green, but } \\
\text { limited space does not significantly affect mission. (All unit equipment can be securely stored.) }\end{array}$} \\
\hline Red: & \multicolumn{2}{|c|}{$\begin{array}{l}\text { Net Square Foot (NSF) Area does not meet space requirements addressed under Green, } \\
\text { significantly and adversely affecting mission. (All unit equipment cannot be securely stored.) }\end{array}$} \\
\hline Component: & Secure Non-Sensitive Storage & Priority: \\
\hline \multirow[t]{6}{*}{ Green: } & \multicolumn{2}{|c|}{ Net Square Foot (NSF) Area meets or exceeds the following based on company personnel (PN): } \\
\hline & $100 \mathrm{PN}$ & 166 \\
\hline & $150 \mathrm{PN}$ & 306 \\
\hline & $200 \mathrm{PN}$ & 504 \\
\hline & Add'I 50 PN & 169 \\
\hline & \multicolumn{2}{|c|}{ Wire Cage Storage constructed IAW AR190-51 and/or AT190-13 } \\
\hline Amber: & \multirow{2}{*}{\multicolumn{2}{|c|}{$\begin{array}{l}\text { Net Square Foot (NSF) Area does not meet space requirements addressed under Green, but } \\
\text { limited space does not significantly affect mission. (All unit equipment can be securely stored.) } \\
\text { Net Square Foot (NSF) Area does not meet space requirements addressed under Green, } \\
\text { significantly and adversely affecting mission. (All unit equipment cannot be securely stored.) }\end{array}$}} \\
\hline Red: & & \\
\hline Component: & Site Orientation & Priority: \\
\hline Green: & \multicolumn{2}{|c|}{$\begin{array}{l}\text { The COF is located in a single fenced battalion centric complex and within } 1 / 4 \text { mile radius of both } \\
\text { unit barracks and motor pool. }\end{array}$} \\
\hline Amber: & \multicolumn{2}{|c|}{$\begin{array}{l}\text { The COF is located within } 1 / 4 \text { mile radius of unit barracks, but more than } 1 / 4 \text { mile from motor } \\
\text { pool. }\end{array}$} \\
\hline Red: & \multicolumn{2}{|c|}{ Neither the unit barracks or motor pool is located within $1 / 4$ mile radius of COF. } \\
\hline Component: & Unit Supply & Priority: \\
\hline \multirow[t]{5}{*}{ Green: } & \multicolumn{2}{|c|}{ Net Square Foot (NSF) Area meets or exceeds the following based on company personnel (PN): } \\
\hline & $100 \mathrm{PN}$ & 367 \\
\hline & $150 \mathrm{PN}$ & 595 \\
\hline & 200 PN & 764 \\
\hline & Add'I 50 PN & 199 \\
\hline Amber: & \multicolumn{2}{|c|}{$\begin{array}{l}\text { Net Square Foot (NSF) Area does not meet space requirements addressed under Green, but } \\
\text { limited space does not significantly affect mission. (All unit equipment can be securely stored.) }\end{array}$} \\
\hline Red: & \multicolumn{2}{|c|}{$\begin{array}{l}\text { Net Square Foot (NSF) Area does not meet space requirements addressed under Green, } \\
\text { significantly and adversely affecting mission. (All unit equipment cannot be securely stored.) }\end{array}$} \\
\hline
\end{tabular}




\begin{tabular}{|c|c|c|c|}
\hline Component: & Communications Equipment Storage & Priority: & 1 \\
\hline \multirow[t]{5}{*}{ Green: } & \multicolumn{3}{|c|}{ Net Square Foot (NSF) Area meets or exceeds the following based on company personnel (PN): } \\
\hline & $100 \mathrm{PN}$ & \multicolumn{2}{|l|}{94} \\
\hline & $150 \mathrm{PN}$ & \multicolumn{2}{|l|}{152} \\
\hline & $200 \mathrm{PN}$ & \multicolumn{2}{|l|}{198} \\
\hline & Add'I 50 PN & \multicolumn{2}{|l|}{52} \\
\hline Amber: & \multicolumn{3}{|c|}{$\begin{array}{l}\text { Net Square Foot (NSF) Area does not meet space requirements addressed under Green, but } \\
\text { limited space does not significantly affect mission. (All unit equipment can be securely stored.) }\end{array}$} \\
\hline Red: & \multicolumn{3}{|c|}{$\begin{array}{l}\text { Net Square Foot (NSF) Area does not meet space requirements addressed under Green, } \\
\text { significantly and adversely affecting mission. (All unit equipment cannot be securely stored.) }\end{array}$} \\
\hline Component: & NBC Storage & Priority: & 1 \\
\hline \multirow[t]{5}{*}{ Green: } & \multicolumn{3}{|c|}{ Net Square Foot (NSF) Area meets or exceeds the following based on company personnel (PN): } \\
\hline & $100 \mathrm{PN}$ & \multicolumn{2}{|l|}{94} \\
\hline & $150 \mathrm{PN}$ & \multicolumn{2}{|l|}{152} \\
\hline & $200 \mathrm{PN}$ & \multicolumn{2}{|l|}{198} \\
\hline & Add'I 50 PN & \multicolumn{2}{|l|}{52} \\
\hline Amber: & \multirow{2}{*}{\multicolumn{3}{|c|}{$\begin{array}{l}\text { Net Square Foot (NSF) Area does not meet space requirements addressed under Green, but } \\
\text { limited space does not significantly affect mission. (All unit equipment can be securely stored.) } \\
\text { Net Square Foot (NSF) Area does not meet space requirements addressed under Green, } \\
\text { significantly and adversely affecting mission. (All unit equipment cannot be securely stored.) }\end{array}$}} \\
\hline Red: & & & \\
\hline Component: & TA-50 Storage & Priority: & 1 \\
\hline \multirow[t]{6}{*}{ Green: } & \multicolumn{3}{|c|}{ Net Square Foot (NSF) Area meets or exceeds the following based on company personnel (PN): } \\
\hline & $100 \mathrm{PN}$ & \multicolumn{2}{|l|}{3,672} \\
\hline & $150 \mathrm{PN}$ & \multicolumn{2}{|l|}{5,292} \\
\hline & $200 \mathrm{PN}$ & \multicolumn{2}{|l|}{6,912} \\
\hline & Add'I 50 PN & \multicolumn{2}{|l|}{1,320} \\
\hline & \multicolumn{3}{|c|}{ One 42" (w) x 24" (d) x 78" (h) locker per soldier assigned to unit. } \\
\hline Amber: & \multicolumn{3}{|c|}{$\begin{array}{l}\text { Net Square Foot (NSF) Area or locker quantities do not meet space requirements addressed under } \\
\text { Green, but limited space does not significantly affect mission. (Supports all non-barracks soldiers.) }\end{array}$} \\
\hline Red: & \multicolumn{3}{|c|}{$\begin{array}{l}\text { Net Square Foot (NSF) Area or locker quantities do not meet space requirements addressed under } \\
\text { Green, significantly and adversely affecting mission. (Does not support non-barracks soldiers.) }\end{array}$} \\
\hline Component: & Admin Module & Priority: & 2 \\
\hline \multirow[t]{9}{*}{ Green: } & \multicolumn{3}{|c|}{ Net Square Foot (NSF) Area meets or exceeds the following based on office type: } \\
\hline & $\mathrm{CO}$ & 150 & \\
\hline & $1 S G$ & 150 & \\
\hline & $\mathrm{XO}$ & 150 & \\
\hline & Command/Platoon Storage & 40 & \\
\hline & Training Room & 150 & \\
\hline & Conference Room & 310 & \\
\hline & Platoon Offices & 150 & \\
\hline & \multicolumn{3}{|c|}{ Admin Module is wired for NIPR/SIPR Communications. } \\
\hline Amber: & \multicolumn{3}{|c|}{ Net Square Foot (NSF) Area meets or exceeds space requirements addressed under Green for all but } \\
\hline
\end{tabular}




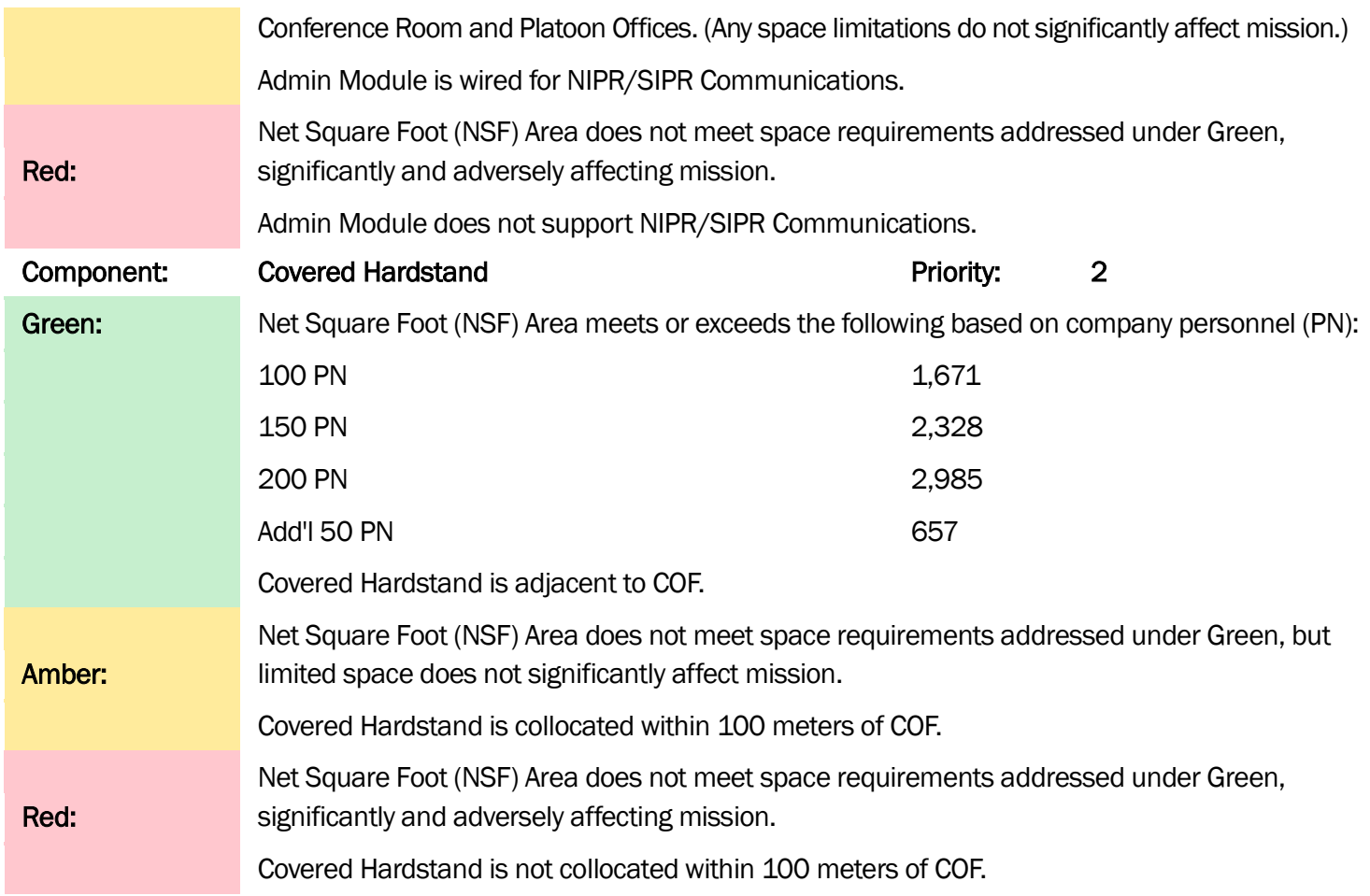




\section{Appendix B: Army Standard Criteria for Tactical Equipment Maintenance Facilities (TEMF)}

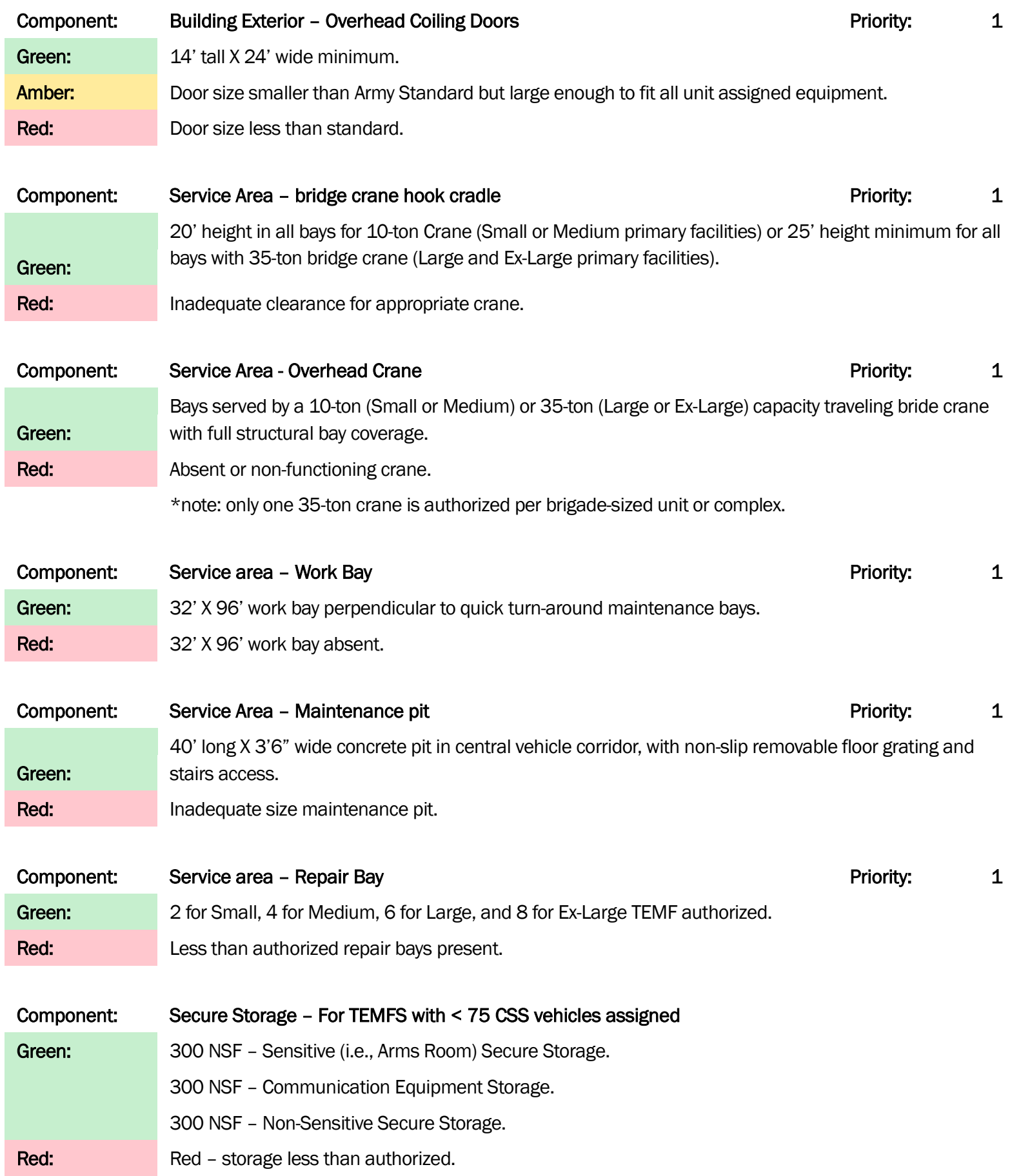




\begin{tabular}{|c|c|c|}
\hline Component: & Unmanned Aircraft System (UAS) Maintenance - when assigned to organization & \\
\hline Green: & NMT 1800 NSF for Class I \& II UAS. & \\
\hline Red: & No allocation for UAS maintenance. & \\
\hline Component: & Parking - Organizational (tactical) parking apron & Priority: \\
\hline Green: & Contiguous pad with room for all organization vehicles assigned. & \\
\hline Red: & Not enough pad space. & \\
\hline \multirow[t]{3}{*}{ Component: } & Hardstand - NIPR/SIPR conduits for telecommunications/power & Priority: \\
\hline & Present. & \\
\hline & Not present. & \\
\hline
\end{tabular}




\section{Appendix C: ISR-I Mission/Functionality Definitions}

\begin{tabular}{|l|l|}
\hline ISR Rating & ISR-I Proposed Definitions \\
\hline F1 & $\begin{array}{l}\text { Minimal or no facility condition deficiencies with negligible or no impact } \\
\text { on the capability to support the tenant organizations' required missions }\end{array}$ \\
\hline F2 & $\begin{array}{l}\text { Moderate facility functional/configuration deficiencies that have limited } \\
\text { impact on the capability to support the tenant organizations' required } \\
\text { missions. All essential/critical functional elements exist }\end{array}$ \\
\hline F3 & $\begin{array}{l}\text { Significant facility functional/configuration deficiencies that impair the } \\
\text { capability to support some of the tenant organizations required missions. } \\
\text { Some essential/critical functional elements may be missing }\end{array}$ \\
\hline F4 & $\begin{array}{l}\text { Major facility functional/configuration deficiencies that present } \\
\text { considerable obstacles to the tenant organizations' accomplishment of } \\
\text { required missions. Some essential/critical functional elements missing. } \\
\text { All temporary facilities are F4 }\end{array}$ \\
\hline F5 & $\begin{array}{l}\text { Asset is nonfunctional and cannot be occupied. Out of service pending } \\
\text { completion of renovation, repair of weather damage, remediation of } \\
\text { environmental contamination, etc }\end{array}$ \\
\hline
\end{tabular}




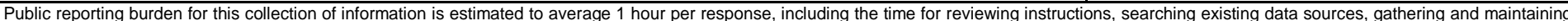

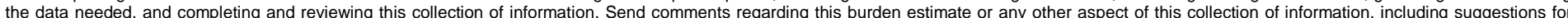

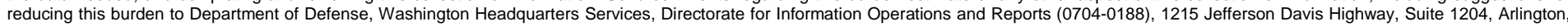

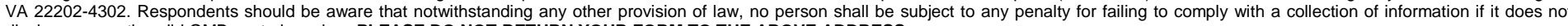
display a currently valid OMB control number. PLEASE DO NOT RETURN YOUR FORM TO THE ABOVE ADDRESS.
1. REPORT DATE (DD-MM-YYYY) 2. REPORT TYPE
3. DATES COVERED (From - To)

September 2011

\section{TITLE AND SUBTITLE}

Final

Army Facility Standard Design and ISR-I Mission Criteria Alignment

5a. CONTRACT NUMBER

5b. GRANT NUMBER

5c. PROGRAM ELEMENT NUMBER

ITTP

6. AUTHOR(S)

Michael N. Grussing, Kelly M. Dilks, and Matthew C. Walters

5d. PROJECT NUMBER

FY10-12E

5e. TASK NUMBER

\section{5f. WORK UNIT NUMBER}

\section{PERFORMING ORGANIZATION NAME(S) AND ADDRESS(ES)}

US Army Engineer Research and Development Center

Construction Engineering Research Laboratory

8. PERFORMING ORGANIZATION REPORT NUMBER

P.O. Box 9005

ERDC/CERL TR-11-37

Champaign, IL 61826-9005

\section{SPONSORING I MONITORING AGENCY NAME(S) AND ADDRESS(ES)}

Office of the Assistant Chief of Staff for Installation Management

Facilities Branch (DAIM-ODF)

2511 Jefferson Davis Highway

Arlington, VA 22202

10. SPONSOR/MONITOR'S ACRONYM(S)

ACSIM

11. SPONSOR/MONITOR'S REPORT NUMBER(S)

\section{DISTRIBUTION / AVAILABILITY STATEMENT}

Approved for public release; distribution is unlimited.

\section{SUPPLEMENTARY NOTES}

\section{ABSTRACT}

This report describes a process for integrating US Army Standards and Standard Designs with assessment criteria used in the Army Installation Status Report for Infrastructure (ISR-I). Army-specific mission-critical facility criteria were identified for two Tier 1 building types, the Tactical Equipment Maintenance Facility and the Company Operations Facility. These criteria were established to meet fundamental performance requirements of the subject facilities. Non-conformance to these criteria could result in the inability of the facility to support its mission, thus requiring restoration, modernization, or replacement. It is imperative that these criteria be incorporated into any assessment process for existing facilities that are used for the same purpose.

The objectives of the current project were to (1) identify Army mission-performance criteria that are embedded in and required by Army Standards and Standard Designs and (2) identify the steps for integrating these mission criteria into the ISR-I to provide decision support for facility Sustainment, Restoration, and Modernization (SRM). Facilities failing to meet mission requirements and not structurally capable of being modernized under SRM are referred to the Military Construction Integrated Process Team for prioritization within the MILCON program. This report describes the results of these efforts and provides recommendations.

\section{SUBJECT TERMS}

Installation Status Report for Infrastructure (ISR-I), Sustainment, Restoration, and Modernization (SRM), Military Construction (MILCON), Army facilities, design criteria, mission criticality

\section{SECURITY CLASSIFICATION OF:}

\section{a. REPORT}

Unclassified

\section{b. ABSTRACT}

Unclassified c. THIS PAGE

Unclassified
17. LIMITATION OF ABSTRACT

\section{NUMBER} OF PAGES

27 19a. NAME OF RESPONSIBLE PERSON

19b. TELEPHONE NUMBER (include area code) 